\title{
COMPARATIVE STUDY BETWEEN BUPIVACAINE ALONE VERSUS BUPIVACAINE WITH FENTANYL, AND BUPIVACAINE WITH DEXAMETHASONE IN ULTRASOUND GUIDED ERECTOR SPINAE PLANE BLOCK FOR POSTOPERATIVE PAIN RELIEF IN PATIENTS UNDERGOING LUMBER SPINE SURGERIES
}

By

\section{Mohamed El-Sadawy Ali Eid, Mohamed Ibrahim Mohamed Hashesh and Mohamed Ahmed El-Badawy Mohamed}

\author{
Department of Anesthesiology and Intensive Care, Faculty of Medicine, Al-Azhar
} University

Corresponding author: Mohamed El-Sadawy Ali Eid;

Mobile: 01012732413; E-mail: mhmdalsdawy37@gmail.com

\begin{abstract}
Background: Pain after lumbar spine surgery is often difficult to control in the post-operative period. The ultrasound-guided erector spinae plane block (ESP) is relatively safe, simple, and there have been no a lot of controlled studies to evaluating its Efficacy.

Objective: To compare the effect of Bupivacaine alone versus Bupivacaine plus Fentanyl, and Bupivacaine plus Dexamethasone in ultrasound-guided erector spinae plane block in lumbar spine surgeries.

Patients and Methods: Ninety patients of both sexes admitted for lumbar surgery. They were randomly allocated into three equal groups: Group A: Control group received bilateral ultrasound-guided erector spinae plane block (bupivacaine alone), group B received bilateral ultrasound-guided ESPB (Bupivacaine + fentanyl) and group C received bilateral ultrasound-guided ESPB (Bupivacaine + Dexamethasone), The following parameters were assessed in the three groups: Heart rate (HR), mean arterial blood pressure (MAP), oxygen saturation (SpO2), end-tidal $\mathrm{CO}$, total narcotic need in first 24 hours, visual analog score (VAS), total amount of opioid in first 24 hours, postoperative nausea and vomiting, and duration of pain relief postoperatively. This study was done at Al-Azhar University Hospitals after approval of the medical ethical committee, from August 2020 till January 2021.

Results: This study showed that the addition of dexamethasone to bupivacaine prolonged the time of block and analgesia duration longer than fentanyl. Also, the addition of fentanyl to bupivacaine prolonged the time of block and analgesia duration longer than bupivacaine alone.

Conclusion: Bilateral ultrasound-guided erector spinae plane block in lumbar spine surgeries is one of the most advantageous adjuvant blocks for improving post-operative pain, and a decrease in opioid side effects. The addition of additive to bupivacaine-like fentanyl, and dexamethasone enhanced the duration of postoperative analgesia till the analgesia request and leads to reduction in pain score in 1 st 24 hours postoperative.
\end{abstract}

Keywords: Erector Spinae, Postoperative pain relief after Lumbar Surgery, fentanyl, Bupivacaine, Dexamethasone. 


\section{INTRODUCTION}

Lumbar surgeries refer to any type of surgery involving any lumbar spine or lower back, between one or more of the L1- S1 level-the type of surgery performed in the spine, including operations for trauma and deformity. The complexity of procedures leads to increase in comorbidities (Attari et al., 2011).

Major lumbar spine surgery causes severe post-operative pain, which typically persists for at least three days. Various studies have reported that maximal pain occurs in the first 4 postoperative hours and gradually declines by the third post-operative day (Calandese and Adduci, 2019).

Post-operative pain management is a significant problem following spinal surgery. Post- operative pain that cannot be well controlled may lead to delayed mobilization, pulmonary and thromboembolic complications, prolonged hospital stays, and chronic pain syndromes. Effective post- operative pain management can also contribute to better surgical outcomes (Devin and McGirt, 2015).

Opioid-based analgesia plays a significant role in the control of postsurgical pain after lumbar surgery; however, use of opioid may lead to significant side effects (e.g., nausea and vomiting) and adverse events (e.g., respiratory depression), which may be associated with significantly longer hospital stays and higher hospital costs in the postsurgical setting (Hurley and $W u$, 2010).

Since these adverse events occur more often in patients receiving higher doses of opioids, it is important to find ways to reduce opioid use in the post-operative period after lumbar spine surgery. Bilateral Ultrasound-Guided Erector Spinae Plane Block in Lumbar Spine Surgeries is a way to improve postoperative pain control and reduce opioid use (Ding et al., 2014).

Erector spinae plane block (ESPB) is an interfascial plane block first described in 2016 by Forero et al. as an effective treatment method for treating thoracic neuropathic pain. Currently, the ESP block is performed as one of the pain management procedures for patients of all generations (newborns, infants, children, adolescents, and adults) undergoing abdominal and thoracic surgeries with minimal complications compared to opioid consumption (Forero et al., 2016).

This study aimed to compare the effect of Bupivacaine alone versus Bupivacaine plus Fentanyl, and Bupivacaine plus Dexamethasone in ultrasound-guided erector spinae plane block in lumbar spine surgeries. The primary outcome was evaluation of pain scores, and the total narcotic consumption during the first 24 hours after surgery. Secondary outcomes included number of rescue analgesic use, post-operative nausea and vomiting (PONV), and duration of post-operative pain relief.

\section{PATIENTS AND METHODS}

This study was a prospective, doubleblinded, and controlled randomization study conducted in the Al-Hussein University Hospital, following approval from the Ethics Committee of the hospital.

Ninety patients at the Department of Anesthesiology and Intensive Care after 
approval of the medical ethical committee at Al-Azhar University Hospitals were scheduled according to the American Society of Anesthesiologist (ASA) physical status I, II of either sex, age (2160) years for lumbar spine surgery under general anesthesia were enrolled in this prospective controlled double- blinded randomized study.

Information about the study was given comprehensively both orally and in written consent form was obtained from every patient.

Inclusion criteria: Adult patients of both sexes with American Society of Anesthesiologists (ASA) physical status I or II aged 21-60 years with BMI less than or equal to 30, The patients have no renal, lung, heart, or liver disorders found on clinical and biochemical tests.

Exclusion criteria: Pregnant females, uncooperative patients with communication difficulties, which might prevent a reliable post-operative assessment, contraindication to regional anesthesia (bleeding disorder, use of any anticoagulants, local infection), known allergy to local anesthetics.

Duration of Study was from August 2020 to January 2021. Patients were randomly divided into three equal groups:

Group (A): Control group received ultrasound guided erector spinae plane (ESP) block with $18 \mathrm{ml}$ of bupivacaine $0.25 \%$ and $2 \mathrm{ml}$ saline $0.9 \%$ per side.

Group (B): Fentanyl group received ultrasound guided ESP block with $18 \mathrm{ml}$ of bupivacaine $0.25 \%$ and $50 \mu \mathrm{g}$ fentanyl diluted with saline to reach total volume $20 \mathrm{ml}$ per side.
Group (C): Dexamethasone group received ultrasound guided ESP block with $18 \mathrm{ml}$ of bupivacaine $0.25 \%$ and 4 $\mathrm{mg}$ dexamethasone diluted with saline to reach total volume $20 \mathrm{ml}$ per side.

All patients were screened for suitability by history, including assessing cardiorespiratory status, a physical examination for heart and chest. Investigation included $\mathrm{CBC}$, coagulation profile, liver function, kidney function, ECG or specific investigations, monitoring (standard monitoring) by pulse oximetry, blood pressure monitoring, $15 \mathrm{~min}$. Interval and capnogram.

Preoxygenation with $100 \%$ oxygen was done for $3 \mathrm{~min}$. General anesthesia was induced in these groups by propofol $(1 \mathrm{mg} / \mathrm{kg})$, fentanyl $(2 \mathrm{mcg} / \mathrm{kg})$ and atracurium $\quad(0.6 \mathrm{mg} / \mathrm{kg}) \quad$ endotracheal intubation performed after full relaxation. Anesthesia was maintained with isoflurane $(1.15 \%-1.2 \%)$ in $100 \%$ oxygen and incremental doses of atracurium (0.1$0.2 \mathrm{mg} / \mathrm{kg}$ ) every 20 minutes to achieve muscle relaxation. Minute ventilation was adjusted to maintain normocapnia (endtidal carbon dioxide; et $\mathrm{CO} 2$, between 34 and $38 \mathrm{~mm} \mathrm{Hg}$ ).

Following induction of general anesthesia, the patient was placed in the prone position. After 20 minutes from repositioning for prone position and stabilization of heamodynamics, and sterilization of the skin of the back, ESPB was performed under ultrasonographic guidance using a linear probe (6-13 $\mathrm{MH}$ ) of ultrasound (Mindray Z5). L4 vertebral level was identified opposite to the supracristal plane (through the highest points of the iliac crest) and the linear ultrasound transducer was placed in a 
longitudinal parasagittal orientation (in plane technique) $3 \mathrm{~cm}$ lateral to the $\mathrm{L} 4$ spinous process, then it was moved cranially to reach L2 spinous process. The erector spinae muscles were identified superficial to the tip of the L2 transverse process and a needle was inserted at the caudal end of the transducer. The needle was advanced through the interfascial plane between the erector spinae and the underlying the tip of transverse process. Thereafter, the local anesthetic was administered into the space. The bilateral ESP blocks was performed by injected on each side : $18 \mathrm{~mL}$ of $0.25 \%$ bupivacaine and $2 \mathrm{ml}$ saline $0.9 \%$ in group (A), $18 \mathrm{~mL}$ of $0.25 \%$ bupivacaine and $50 \mu \mathrm{g}$ fentanyl diluted with saline to reach total volume $20 \mathrm{ml}$ in group (B), and $18 \mathrm{ml}$ of bupivacaine $0.25 \%$ and $4 \mathrm{mg}$ dexamethasone diluted with saline to reach total volume $20 \mathrm{ml}$ in group $(\mathrm{C})$ into the fascial plane between the deep surface of the erector spinae muscle and the transverse processes of the lumbar vertebrae for pain management after lumbar spine surgery.

At the end of the surgery, anesthesia discontinued, and residual neuromuscular blockade was antagonized with neostigmine $(0.08 \mathrm{mg} / \mathrm{kg})$ and atropine $(0.02 \mathrm{mg} / \mathrm{kg})$, followed by extubation. When the patients became fully awake, patients were transferred to the post anesthesia care unit (PACU). All patients in the study were subjected to paracetamol $1000 \mathrm{mg}$ infusion intravenously every 8 hours. Patients were allowed to receive incremental doses of morphine (0.05 $\mathrm{mg} / \mathrm{kg}$ ) intravenously if VAS was $\geq 4$.

Statistical analysis: Recorded data were analyzed using the statistical package for the social sciences version. 20.0 (SPSS Inc., Chicago, Illinois, USA). ANOVA test was used for comparison among different times in the same group in quantitative data. Quantitative data were expressed as mean \pm standard deviation (SD) and range. Qualitative data were expressed as frequency and percentage the confidence interval was set to $95 \%$ and the margin of error accepted was set to $5 \%$. P-value $<0.05$ was considered significant. $\mathrm{P}$ value was calculated by ANOV of followed by Post-hoc test, orbg Krusaall- Wallis test. 


\section{RESULTS}

There was no statistically significant difference found between the three studied groups regarding age and sex with p-value $=0.111$ and 0.162 , respectively. Also, the table shows that there was no statistically significant difference found between the three studied groups regarding weight with p-value $=0.126$. Finally, no statistically significant difference was found between the three studied groups regarding ASA classification (Table 1).

Table (1): Comparison between the three groups regarding age, sex, ASA and body weight variations

\begin{tabular}{|c|c|c|c|c|}
\hline Demographic data $\quad$ Groups & $\begin{array}{c}\text { Group A } \\
(\mathbf{N}=\mathbf{3 0})\end{array}$ & $\begin{array}{c}\text { Group B } \\
(\mathbf{N}=30)\end{array}$ & $\begin{array}{c}\text { Group C } \\
(\mathbf{N}=\mathbf{3 0})\end{array}$ & P-value \\
\hline Age (years) & $37.93 \pm 8.17$ & $35.03 \pm 10.86$ & $40.17 \pm 8.93$ & 0.111 \\
\hline \multicolumn{5}{|c|}{ Sex } \\
\hline Female & $7(23.3 \%)$ & $14(46.7 \%)$ & $10(33.3 \%)$ & \multirow[b]{2}{*}{0.162} \\
\hline Male & $23(76.7 \%)$ & $16(53.3 \%)$ & $20(66.7 \%)$ & \\
\hline Weight (kg) & $77 \pm 8.46$ & $80.63 \pm 7.69$ & $80.6 \pm 7.37$ & 0.126 \\
\hline \multicolumn{5}{|c|}{ ASA } \\
\hline I & $21(70 \%)$ & $23(76.7 \%)$ & $17(56.7 \%)$ & \multirow[b]{2}{*}{0.241} \\
\hline II & $9(30 \%)$ & $7(23.3 \%)$ & $13(43.3 \%)$ & \\
\hline
\end{tabular}

There was no statistically significant difference found between the three studied groups regarding heart rate at baseline, 30 min, $60 \mathrm{~min}, 90 \mathrm{~min}$ and $120 \mathrm{~min}$ with $\mathrm{p}$ value $=0.516,0.608,0.990,0.587$ and
0.919 respectively. Also shows that there was no statistically significant difference found between the three studied groups regarding heart rate post-operatively (Table 2).

Table (2): Comparison between the three groups regarding heart rate at baseline, intra-operative and post-operative.

\begin{tabular}{|c|c|c|c|c|c|c|c|}
\hline \multirow{2}{*}{$\begin{array}{c}\text { Heart rate } \\
\text { (beat/min.) }\end{array}$} & $\begin{array}{c}\text { Group A } \\
\text { (N=30) }\end{array}$ & \multicolumn{2}{c|}{$\begin{array}{c}\text { Group B } \\
\text { (N=30) }\end{array}$} & \multicolumn{2}{c|}{$\begin{array}{c}\text { Group C } \\
(\mathbf{N = 3 0})\end{array}$} & \multirow{2}{*}{ P-value } \\
\cline { 2 - 7 } & Mean & SD & Mean & SD & Mean & SD & \\
\hline Base line & 86.73 & 9.15 & 84.57 & 9.74 & 87.37 & 10.61 & 0.516 \\
\hline \multicolumn{7}{|c|}{ Intra-operatively } \\
\hline $30 \mathrm{~min}$ & 79.13 & 14.34 & 80.33 & 4.80 & 81.57 & 6.12 & 0.608 \\
\hline $60 \mathrm{~min}$ & 81.20 & 5.68 & 81.00 & 5.11 & 81.07 & 5.95 & 0.990 \\
\hline $90 \mathrm{~min}$ & 77.37 & 7.80 & 79.30 & 6.65 & 78.83 & 8.12 & 0.587 \\
\hline $120 \mathrm{~min}$ & 70.10 & 6.12 & 70.73 & 5.65 & 70.33 & 6.31 & 0.919 \\
\hline \multicolumn{7}{|c|}{ Post-operatively } \\
\hline $1 \mathrm{hr}$ & 74.93 & 9.79 & 75.97 & 9.67 & 74.13 & 8.55 & 0.749 \\
\hline $4 \mathrm{hr}$ & 80.67 & 6.83 & 80.47 & 6.13 & 80.73 & 6.65 & 0.987 \\
\hline $8 \mathrm{hr}$ & 82.20 & 4.60 & 82.03 & 4.48 & 83.03 & 4.57 & 0.661 \\
\hline $12 \mathrm{hr}$ & 85.03 & 5.52 & 86.33 & 5.76 & 85.50 & 6.53 & 0.694 \\
\hline $16 \mathrm{hr}$ & 91.50 & 6.05 & 89.60 & 6.61 & 89.17 & 5.83 & 0.302 \\
\hline $20 \mathrm{hr}$ & 89.67 & 6.10 & 87.43 & 4.80 & 88.37 & 4.92 & 0.267 \\
\hline $24 \mathrm{hr}$ & 91.57 & 4.86 & 89.13 & 3.97 & 90.37 & 3.85 & 0.092 \\
\hline $28 \mathrm{hr}$ & 92.87 & 4.92 & 93.03 & 4.81 & 92.30 & 5.03 & 0.833 \\
\hline
\end{tabular}


There was no statistically significant difference found between the three studied groups regarding $\mathrm{MABP}(\mathrm{mmHg})$ at baseline, $30 \mathrm{~min}, 60 \mathrm{~min}, 90 \mathrm{~min}$ and 120 min with $\mathrm{p}$-value $=0.475,0.210,0.092$,
0.959 and 0.203 respectively. Also, there was no statistically significant difference found between the three studied groups regarding mean arterial blood pressure post- operatively (Table 3).

Table (3): Comparison between the three groups regarding MABP at baseline, intra-operative and post-operative

\begin{tabular}{|c|c|c|c|c|c|c|c|}
\hline \multirow{8}{*}{$\begin{array}{c}\text { MABP } \\
\text { Groups }\end{array}$} & $\begin{array}{c}\text { Group A } \\
(\mathbf{N}=\mathbf{3 0})\end{array}$ & \multicolumn{2}{c|}{$\begin{array}{c}\text { Group B } \\
(\mathbf{N = 3 0})\end{array}$} & \multicolumn{2}{c|}{$\begin{array}{c}\text { Group C } \\
(\mathbf{N = 3 0})\end{array}$} & \multirow{2}{*}{ P-value } \\
\cline { 2 - 8 } & Mean & SD & Mean & SD & Mean & SD & \\
\hline Base line & 97.23 & 9.10 & 96.37 & 7.48 & 94.77 & 7.02 & 0.475 \\
\hline \multicolumn{8}{|c|}{ Intra operatively } \\
\hline 30min. & 85.10 & 7.67 & 85.50 & 6.93 & 82.47 & 6.85 & 0.210 \\
\hline 60min. & 69.53 & 6.40 & 69.50 & 6.18 & 72.57 & 5.86 & 0.092 \\
\hline 90min. & 63.60 & 3.79 & 63.40 & 3.05 & 63.33 & 4.16 & 0.959 \\
\hline 120min. & 59.50 & 1.11 & 59.27 & 1.11 & 60.53 & 4.77 & 0.203 \\
\hline \multicolumn{7}{|c|}{ Post-operatively } \\
\hline 1hr. & 79.87 & 8.41 & 77.00 & 6.28 & 80.97 & 7.25 & 0.104 \\
\hline 4hrs. & 89.00 & 5.90 & 92.50 & 6.69 & 89.43 & 6.37 & 0.071 \\
\hline 8hrs. & 86.33 & 9.20 & 85.30 & 6.73 & 89.50 & 6.63 & 0.090 \\
\hline 12hrs. & 86.70 & 4.24 & 87.20 & 7.10 & 88.13 & 4.46 & 0.585 \\
\hline 16hrs. & 90.93 & 5.24 & 90.43 & 6.46 & 92.73 & 5.86 & 0.285 \\
\hline 20hrs. & 91.07 & 5.32 & 90.20 & 6.29 & 91.80 & 5.90 & 0.572 \\
\hline 24hrs. & 91.13 & 5.14 & 90.10 & 6.33 & 92.40 & 6.27 & 0.328 \\
\hline 28hrs. & 96.37 & 4.56 & 96.67 & 4.37 & 96.90 & 4.50 & 0.899 \\
\hline
\end{tabular}

There were statistically significant differences found between the three studied groups regarding vas score at $12^{\text {th }}$, $16^{\text {th }}, 20^{\text {th }}$ and $20^{\text {th }}$ hours post-operative with p-value $=<0.001,<0.001,<0.001$,
$<0.001,<0.01$ while at $1^{\text {st }}, 4^{\text {th }}, 8^{\text {th }}, 28^{\text {th }}$ hours post-operative there was no statistically significant difference found between the three studied groups with $\mathrm{p}$ value $<0.001$ (Table 4).

Table (4): Comparison between the three groups regarding vas score post-operative.

\begin{tabular}{|c|c|c|c|c|c|c|c|c|c|c|}
\hline \multirow{2}{*}{ GAS } & \multicolumn{2}{|c|}{$\begin{array}{c}\text { Group A } \\
(\mathbf{N}=\mathbf{3 0})\end{array}$} & \multicolumn{2}{|c|}{$\begin{array}{c}\text { Group B } \\
(\mathbf{N}=\mathbf{3 0})\end{array}$} & \multicolumn{2}{|c|}{$\begin{array}{c}\text { Group C } \\
(\mathbf{N}=\mathbf{3 0})\end{array}$} & \multirow[t]{2}{*}{ P-value } & \multirow[b]{2}{*}{$A \& F$} & \multirow[b]{2}{*}{ A\&D } & \multirow[b]{2}{*}{$\mathrm{F} \& \mathrm{D}$} \\
\hline & Mean & SD & Mean & SD & Mean & SD & & & & \\
\hline $1 \mathrm{hr}$. & 1.47 & 1.04 & 1.67 & 1.12 & 1.80 & 1.03 & 0.479 & & & \\
\hline $4 \mathrm{hrs}$. & 2.40 & 0.89 & 2.40 & 1.04 & 2.37 & 1.10 & 0.989 & & & \\
\hline $8 \mathrm{hrs}$. & 3.10 & 0.80 & 3.13 & 0.63 & 3.10 & 0.66 & 0.978 & & & \\
\hline $12 \mathrm{hrs}$. & 4.03 & 0.85 & 3.53 & 0.73 & 3.17 & 0.83 & $<0.001$ & 0.048 & $<0.001 * *$ & 0.189 \\
\hline $16 \mathrm{hrs}$. & 5.13 & 0.86 & 3.93 & 0.78 & 3.07 & 0.69 & $<0.0$ & $<0.001 * *$ & $<0.001 * *$ & $<0.001 * *$ \\
\hline 20hrs. & 5.00 & 0.83 & 5.00 & 0.87 & 3.93 & 0.87 & $<0.0$ & 1.000 & $<0.001 * *$ & $<0.001 * *$ \\
\hline $24 \mathrm{hrs}$. & 4.90 & 0.84 & 5.20 & 0.85 & 4.07 & 0.83 & $<0.001$ & 0.354 & $<0.001 * *$ & $<0.001 * *$ \\
\hline $28 \mathrm{hrs}$. & 5.13 & 0.68 & 5.03 & 0.85 & 5.00 & 0.79 & 0.787 & & & \\
\hline
\end{tabular}


There were statistically significant differences found between the three studied groups regarding number of patient need narcotic post-operative at $12^{\text {th }}$ hour post-operative with $\mathrm{p}$-value $<0.05$,
Also high statistically significant difference between the three groups as regard Total narcotic need at $16^{\text {th }}$ and $20^{\text {th }}$ hour with p-value $<0.001$ (Table 5).

Table (5): Comparison between the three groups regarding number of patient need narcotic in the first $24 \mathrm{hrs}$ post-operative

\begin{tabular}{|c|c|c|c|c|c|c|c|}
\hline \multirow{2}{*}{$\begin{array}{l}\text { Groups } \\
\text { Total narcotic }\end{array}$} & $\begin{array}{c}\text { Group A } \\
\text { need }\end{array}$ & \multicolumn{2}{|c|}{$\begin{array}{c}\text { Group B } \\
(\mathbf{N = 3 0})\end{array}$} & \multicolumn{2}{c|}{$\begin{array}{c}\text { Group C } \\
(\mathbf{N = 3 0})\end{array}$} & \multirow{2}{*}{ P-value } \\
\cline { 2 - 8 } & $\mathrm{N}$ & $\%$ & $\mathrm{~N}$ & $\%$ & $\mathrm{~N}$ & $\%$ & \\
\hline 1hr. & 0 & 0.0 & 0 & 0.0 & 0 & 0.0 & 1.000 \\
\hline 4hrs. & 0 & 0.0 & 0 & 0.0 & 0 & 0.0 & 1.000 \\
\hline 8hrs. & 0 & 0.0 & 0 & 0.0 & 0 & 0.0 & 1.000 \\
\hline 12hrs. & 5 & 16.7 & 0 & 0.0 & 0 & 0.0 & 0.005 \\
\hline 16hrs. & 10 & 33.3 & 0 & 0.0 & 0 & 0.0 & $<0.001$ \\
\hline 20hrs. & 14 & 46.7 & 10 & 33.3 & 0 & 0.0 & $<0.001$ \\
\hline 24hrs. & 15 & 50.0 & 15 & 50.0 & 15 & 50.0 & 1.000 \\
\hline
\end{tabular}

There was high statistically significant difference found between the three studied groups regarding the Total amount of narcotic use in the first $24 \mathrm{hrs}$ in $\mathrm{mg}$ with P-value $<0.001$ (Table 6).

Table (6): Comparison between the three regarding Total amount of narcotic use in first $24 \mathrm{hrs}$ in $\mathrm{mg}$

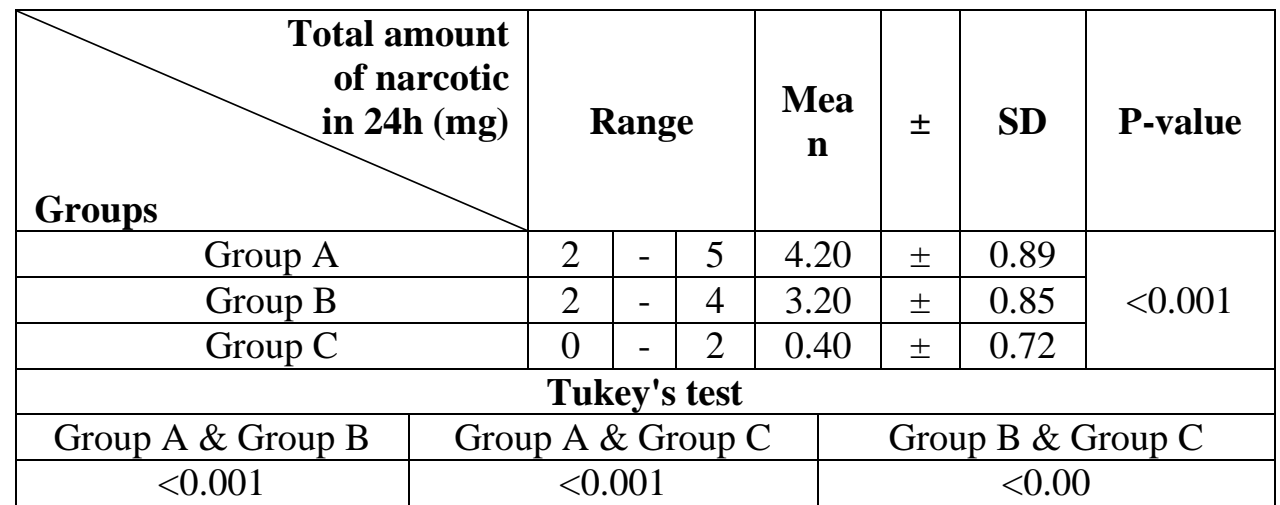


There were statistically significant differences between the three groups as regard Duration of post-operative pain relief with $p$-value $<0.001$ (Table 7).

Table (7): Comparison between the three groups as regard Duration of postoperative pain relief

\begin{tabular}{|c|c|c|c|c|}
\hline $\begin{array}{r}\text { Duration of post.op. pain } \\
\text { relief (hrs) }\end{array}$ & Range & Mean \pm SD & $\mathbf{F}$ & P-value \\
\hline Groups & & & & \\
\hline Group A & $10-14$ & $12.23 \pm 1.48$ & \multirow{3}{*}{357.969} & \multirow{3}{*}{$<0.001$} \\
\hline Group B & $15-19$ & $17.00 \pm 1.23$ & & \\
\hline Group C & $20-26$ & $22.87 \pm 1.85$ & & \\
\hline \multicolumn{5}{|c|}{ Tukey's test } \\
\hline Group A \& Group B & \multicolumn{2}{|c|}{ Group A \& Group C } & \multicolumn{2}{|c|}{ Group B \& Group C } \\
\hline$<0.001$ & \multicolumn{2}{|c|}{$<0.001$} & \multicolumn{2}{|c|}{$<0.001$} \\
\hline
\end{tabular}

There was no statistically significant difference between three groups as regard the nausea and vomiting with $\mathrm{p}$-value $>0.05$ (Table 8).

Table (8): Comparison between the three groups as regard nausea and vomiting.

\begin{tabular}{|c|c|c|c|c|c|c|c|}
\hline \multirow{2}{*}{ Groups } & \multicolumn{2}{|c|}{$\begin{array}{c}\text { Group A } \\
(\mathbf{N = 3 0})\end{array}$} & \multicolumn{2}{c|}{$\begin{array}{c}\text { Group B } \\
(\mathbf{N = 3 0})\end{array}$} & \multicolumn{2}{c|}{$\begin{array}{c}\text { Group C } \\
(\mathbf{N = 3 0})\end{array}$} & \multirow{2}{*}{ P-value } \\
\cline { 2 - 7 } Nausea and vomiting & $\mathrm{N}$ & $\%$ & $\mathrm{~N}$ & $\%$ & $\mathrm{~N}$ & $\%$ & \\
\hline 1hr. & 8 & 26.7 & 10 & 33.3 & 8 & 26.7 & 0.805 \\
\hline 4hrs. & 6 & 20.0 & 8 & 26.7 & 6 & 20.0 & 0.773 \\
\hline 8hrs. & 5 & 16.7 & 5 & 16.7 & 4 & 13.3 & 0.919 \\
\hline 12hrs. & 0 & 0.0 & 0 & 0.0 & 0 & 0.0 & 1.000 \\
\hline 16hrs. & 0 & 0.0 & 0 & 0.0 & 0 & 0.0 & 1.000 \\
\hline 20hrs. & 0 & 0.0 & 0 & 0.0 & 0 & 0.0 & 1.000 \\
\hline 24hrs. & 0 & 0.0 & 0 & 0.0 & 0 & 0.0 & 1.000 \\
\hline 28hrs. & 0 & 0.0 & 0 & 0.0 & 0 & 0.0 & 1.000 \\
\hline
\end{tabular}

\section{DISCUSSION}

In this study, statistical analysis of the patients' demographic data did not show any significant differences between the three groups, as regards age, sex, ASA and weight. The present study also show intraoperative statistically insignificant in SPo2, ETCO2, intraoperative and postoperative heart rate, MAPB.

These results agreed with a study done by Altiparmak et al. (2019) who studied efficacy of ultrasound-guided erector spinae plane block for analgesia after laparoscopic cholecystectomy and found that variations in heart rates over time were significantly different in the two groups. Also, he found the patients' MAP values differed significantly at different time points.

In the current study, there was a reduction in post-operative pain incidence and severity, which was demonstrated by comparing the visual analog scale (VAS) measurements among the three groups. VAS measurements in group $\mathrm{B}$ and $\mathrm{C}$ were lower than in group $\mathrm{A}$ at $12^{\text {th }}$ and 
$16^{\text {th }}$ hour. Also, VAS measurements in group B were lower than in group C and $A$ at $20^{\text {th }}$ and $24^{\text {th }}$ hour. The VAS measurements also showed nonstatistically significant difference between three groups at the $1^{\text {st }}, 4^{\text {th }}, 8^{\text {th }}, 28^{\text {th }}$ hours. Group A patients had the highest pain scores, and were the first to ask for rescue analgesia, and consumed the highest amount of analgesia. Therefore, they had the highest total analgesic consumption in the first 24 hours postoperatively in comparison to patients of the other B and $\mathrm{C}$ groups. On the contrary, the group $\mathrm{C}$ patients had the lowest pain scores, were the last to call for intravenous analgesia, and consumed the lowest total systemic analgesia dose.

This current study showed that nonsignificant reported post-operative nausea and vomiting. The current study agreed with the results of Ueshima et al. (2019) who showed no significant difference in the incidence of complications between the two groups, and that erector spinae plane (ESP) block provides effective postoperative analgesic effect for 24 hours in patients undergoing lumbar spinal surgery.

The current study also agreed with the results of Singh et al. (2020) found that patient satisfaction was assessed 24 hours after surgery, and post-operative morphine consumption was significantly lower in patients in the ESP group compared with those in the control group. Pain scores were lower in the ESP block group compared with the control group. Patient satisfaction scores were more favorable in the block group. They conclude that USguided ESP block reduces post-operative opioid requirement and improves patient satisfaction compared with standard analgesia in lumbar spine surgery patients.

The present results agreed with a study done by Aksu et al. (2019) who studied the effect of erector spinae plane block on postoperative pain following laparoscopic cholecystectomy and showed postoperative morphine consumption which was significantly lower in patients in the ESP group compared with those in the control group. All patients in the control group required supplemental morphine compared with the ESP block group. Pain scores were lower in the ESP block group than the control.

The present results agreed with a study done by Karaca and Pinar (2020) who studied the efficacy of ultrasound-guided erector spinae plane block for postoperative analgesia in laparoscopic cholecystectomy: The control group (Group A) who received only intravenous (IV) patient-controlled analgesia (PCA) and the ESPB Group (Group B) who received bilateral ESPB (bupivacaine $0.25,50 \mathrm{~mL})$ IV PCA showing that numeric rating scores in Group B were lower in the post anesthesia care unit (PACU) at 1st, 2nd, 4th, 6th hours, and 8th hour. The fentanyl consumption during post-operative period was lower in Group B. PACU, and hospital stay was shorter in Group B. Need for rescue analgesia was lower in Group B. Intraoperative fentanyl requirement was lower in Group B. Unassisted walking time was shorter in Group B and No block related complications were encountered.

Swain et al. (2017) studied that adjuvants or additives are often used with local anesthetics for its synergistic effect by prolonging the duration of sensory- 
motor block, limiting the cumulative dose requirement of local anesthetics and prolongation of duration of analgesia. The addition of additive to bupivacaine like fentanyl and dexamethasone enhanced the duration of post-operative analgesia till the analgesia request and leads to reduction in pain score in 1 st 24 hours post-operative.

\section{CONCLUSION}

Ultrasound-guided erector spinae plane block reduced post-operative Narcotic consumption and pain scores in the first $24 \mathrm{~h}$ after lumbar spine surgeries. The addition of dexamethasone to bupivacaine prolonge the time of block and analgesia duration longer than fentanyl and bupivacaine alone and the addition of fentanyl to bupivacaine prolonged the time of block and analgesia duration longer than bupivacaine alone.

\section{REFERENCES}

1. Aksu C, Kuş A, Yörükoğlu H, Kılıç L and Gürkan Y (2019): The Effect of Erector Spinae Plane Block on Postoperative Pain Following Laparoscopic Cholecystectomy. Journal of Anaesthology and Reanimation Specialists Society, 27(1): 9-14.

2. Altiparmak B, Toker MK, Uysal Aİ, Kuşçu Y and Demirbilek SG (2019): Eficácia do bloqueio do plano do músculo eretor da espinha guiado por ultrassom para analgesia após colecistectomia laparoscópica: um estudo controlado randômico [Efficacy of ultrasoundguided erector spinae plane block for analgesia after laparoscopic cholecystectomy: a randomized controlled trial]. Rev Bras Anestesiol., 69(6):561-568.

3. Attari MA, Mirhosseini SA, Honarmand A and Safavi MR (2011): Spinal anesthesia versus general anesthesia for elective lumbar spine surgery: Arandomized clinical trial. Journal of research in medical sciences: the official Journal of Isfahan University of Medical Sciences, 16(4): 524-28.
4. Calandese F and Adduci A (2019): Erector spinae plane block for acute post-operative pain management after anterior thoracolumbar spine surgery. J Clin Anesth., 52:55-56.

5. Devin CJ and McGirt MJ (2015): The best evidence in multimodal pain management in spine surgery and means of assessing postoperative pain and functional outcomes. Journal of Clinical Neuroscience, 22(6): 930938.

6. Ding $X$, Jin S, Niu X, Wang T, Zhao $X$, Ren H, Tong Y and Li Q (2014): Morphine with adjuvant ketamine versus higher dose of morphine alone for acute pain: a metaanalysis. International Journal of Clinical and Experimental Medicine, 7(9):2504-11.

7. Forero M, Adhikary SD, Lopez H, Tsui C and Chin KJ (2016): The erector spinae plane block a novel analgesic technique in thoracic neuropathic pain. Regional Anesthesia and Pain Medicine, 41(5): 621627.

8. Hurley RW and Wu CL (2010): Acute postoperative pain. Miller's Anesthesia, 7: 275787.

9. Karaca $O$ and Pinar $H$ (2020): Efficacy of Ultrasound-Guided Erector Spinae Plane Block for Postoperative Analgesia in Laparoscopic Cholecystectomy. Journal of Anaesthology and Reanimation Specialists Society, 10(5): 179-187.

10. Singh S, Choudhary NK, Lalin $D$ and Verma VK (2020): Bilateral ultrasoundguided erector spinae plane block for postoperative analgesia in lumbar spine surgery: a randomized control trial. Journal of Neurosurgical Anesthesiology, 32(4):330-4.

11. Swain A, Nag DS, Sahu S and Samaddar DP (2017): Adjuvant to local anesthesics: Current understanding and future trends. World J Clin Cases, 5(8):307-311.

12. Ueshima $H$, Inagaki $M$, Toyone $T$ and Otake H (2019): Efficacy of the erector spinae plane block for lumbar spinal surgery: a retrospective study. Asian Spine Journal, 13(2): 254-58. 
در اسة مقارنة بين بو بيفاكين وحده مقابل بوبيفاكين مع فنتانيل

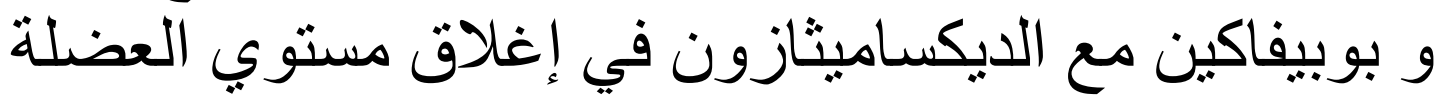

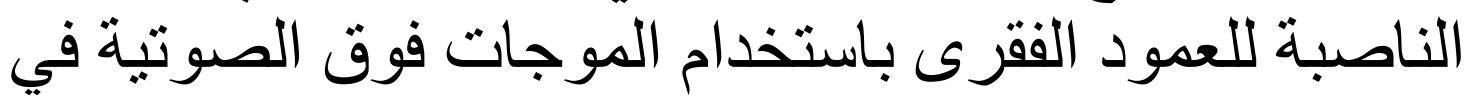
تسكين الآلام ما بعد جر احات الفقرات القطنية

محمد السعداوى على عيد، محمد إبراهيم محمد حشيش، محمد أحمد البدوى محمد قسم التخدير والرعاية المركزة، كلية الطب، جامعة الأزهر

E-mail: $\underline{\text { mhmdalsdawy37@ gmail.com }}$

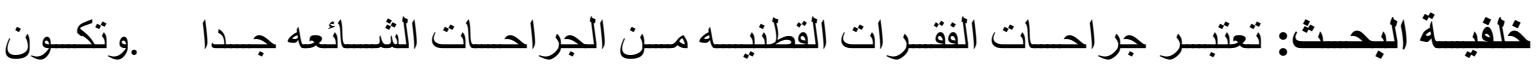

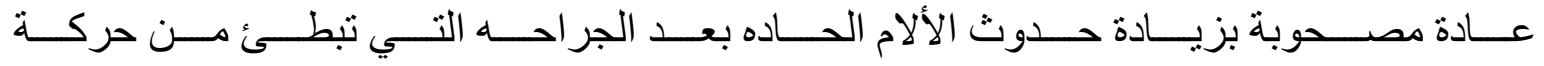
المريض مما يزيد نسبة حدوث الكثير من المضاعفات.

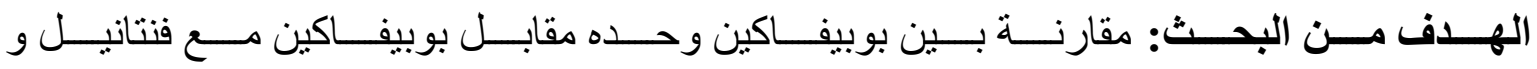

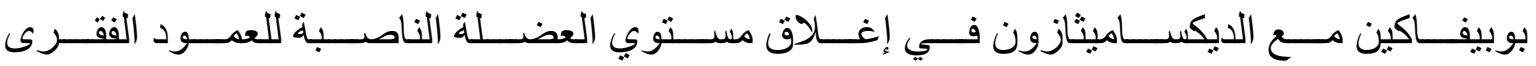

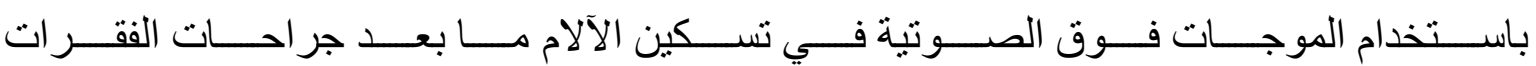
القطنية.

المرضـــي وطـــرق البحــث: اجريـــت هــذه الدر اســـه علــي 90 مـــريض تتــر اوح اعمــار هم

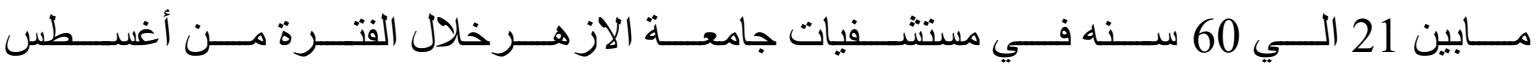

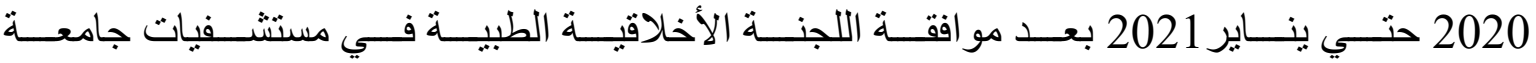

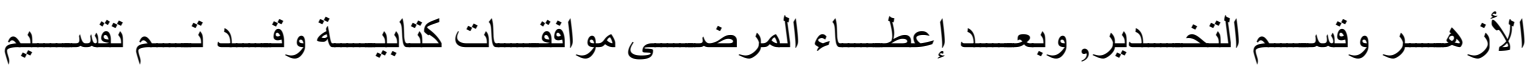

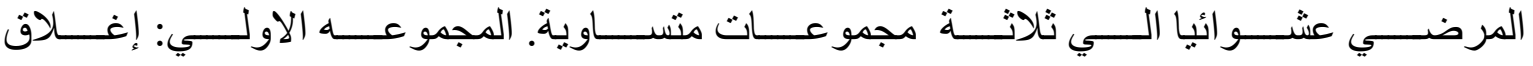

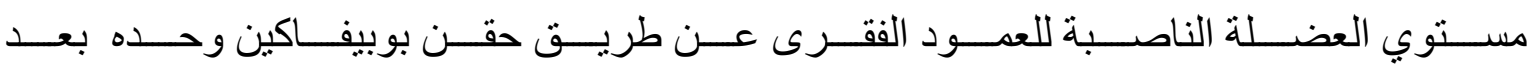
إجــر اء التخــدير الكلــي، و المجموعـــه الثانيــة : إغــلاق مســتوي العضــلـة الناصـــبة للعدـــود

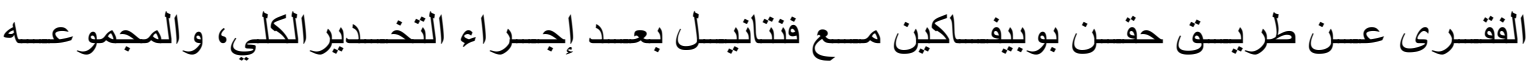

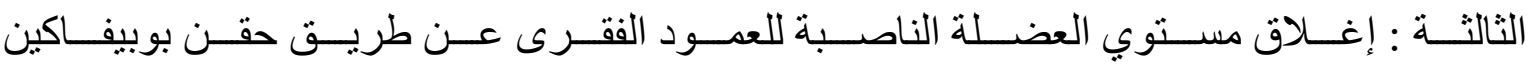
مع الديكساميثازون بعد إجر اء التخدير الكلي. 


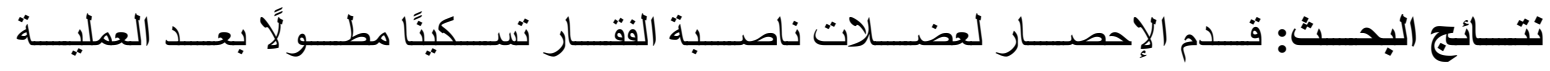

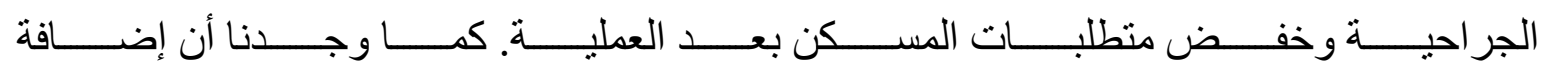

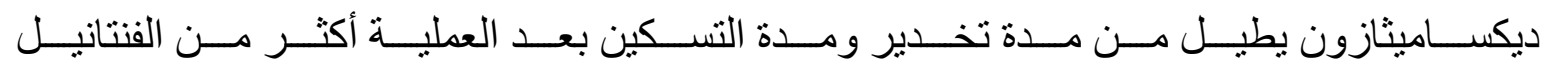

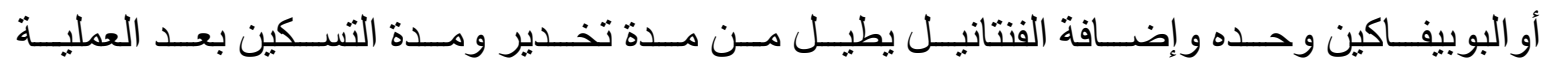
أكثر من البوبيفاكين وحده.

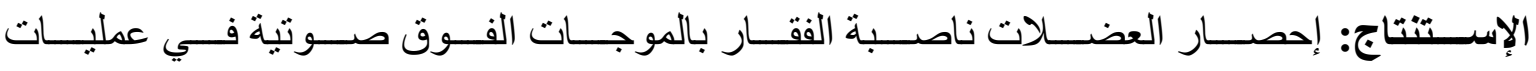

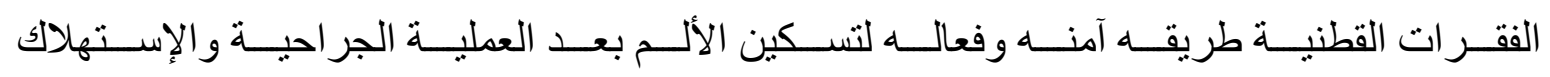

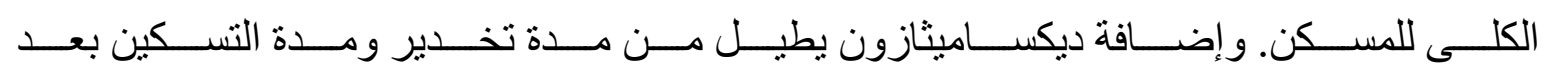

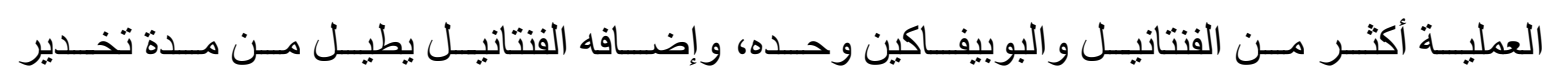
ومدة التسكين بعد العملية أكثر من البوبيفاكين وحده.

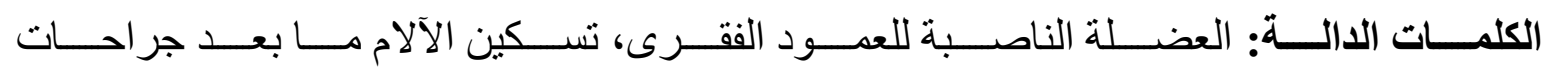
الفقرات القطنية، بوبيفاكين، فنتانيل، الديكساميثازون. 